\title{
The Influence of Transformational Leadership on Job Satisfaction, Organizational Commitment, and Employee Performance
}

\author{
Marnis Atmojo \\ Universitas Riau, Riau
}

\begin{tabular}{|c|c|}
\hline ARTICLE INFO & A B S T RACT \\
\hline $\begin{array}{l}\text { Received: January 25, } 2012 \\
\text { Final revision: June 12, } 2012\end{array}$ & \multirow[b]{2}{*}{$\begin{array}{l}\text { This research has four main objectives; first, to prove and analyze the } \\
\text { influence of transformational leadership towards employee job satis- } \\
\text { faction; Second, to prove and analyze the influence of transformational } \\
\text { leadership towards organizational commitment; Third, to prove and } \\
\text { analyze the influence of transformational leadership towards employee } \\
\text { performance; Fourth, to prove and analyze the influence of organiza- } \\
\text { tion commitment towards the employee performance. This research } \\
\text { involved } 146 \text { members of middle management as our research sample } \\
\text { namely Head of Department, Plantation Manager, Plant Manager, } \\
\text { Head of Bureau/Division, Head Assistant, Head of Strategic Business } \\
\text { Unit (SBU), Chief Engineer and Head of Hospital Service. Structural } \\
\text { Equation Modeling (SEM) was used to test and analyze relationship } \\
\text { among the research variables. Research findings are transformational } \\
\text { leadership significantly influences job satisfaction, transformational } \\
\text { leadership significantly influences the organization commitment. The } \\
\text { job satisfaction is shown to have significant influence on employee } \\
\text { performance, and organization commitment significantly influences } \\
\text { the employee performance.. }\end{array}$} \\
\hline $\begin{array}{l}\text { Keywords: } \\
\text { Transformational Leadership, } \\
\text { Job Satisfaction, } \\
\text { Organizational Commitment, } \\
\text { Employee Performance }\end{array}$ & \\
\hline
\end{tabular}

$\mathrm{S}$ tate-owned enterprise (BUMN), is one of the important business players that largely contributes to national development, aimed at developing people prosperity. Highly valuable state-owned enterprise (BUMN) requires professionalism in its management for a well run enterprise, without creating burden to the government.

PT Perkebunan Nusantara V Riau (PTPN V) is one of the state-owned plantation enterprises in Indonesia. It is a consolidation of ex- PT Perkebunan II, PT Per- 
kebunan IV and PT Perkebunan V in Riau Province. PTPN V manages palm, rubber and cocoa cultivation. However, since 2001, the company has been focusing only on the palm and rubber cultivation.

The total number of employees, total production and employee productivity of PTPN V, Riau are shown in Table 1.

It is evident from Table 1 that employee productivity in 2006 was $16.78 \%$ lower than that of 2005 . This is related to declining employee performance which later decreases the production output. One of the possible causes is the change in organizational structure due to a merger of three PTPN companies to become a single PTPN V entity, which then results in alteration of organizational leadership. Leadership strongly influences company's overall performance. In 2007, productivity showed a positive trend with the increase of 7.67 $\%$ compared to that of previous year. A minute increase in productivity of $1.31 \%$ occured in 2008 . While in 2009, employee productivity plummeted by $11.30 \%$, affecting the company's profit achievement. This situation clearly indicates declining PTPN V employee's performance. The downtrend is possibly related to the merger adaptation process to several different leadership characteristics as a result of government consolidation program.

State-owned plantation enterprise follows beurocratic management style which possibly be adopted from the government beurocracy. To date, several state-owned plantation enterprises have transformed to real corporations shedding their beurocratic patterns. The transformation from "bureaucracy" to "corporation" remains the main agenda of state-owned plantation enterprises.

Furthermore, inspite of the state-owned plantation's organizational structure that support decentralized authority, the bureaucracy issue exists due on the ineffectiveness of authority delegation as a result of paternalistic culture

Paternalism is different from leadership. While leadershipis the process of influencing others to achieve organizational benefits, paternalism is identical to superiority. Paternalism is a value system with absolute dependence to the leader. In paternalistic organization, the member of organization assumes that the authority and accountability relies on the leader. Therefore, the responsibility of organizational development relies primarily on the leader. In paternalistic organization, the application of modern management principles which is based on Good Corporate Governance where professionalism becomes the attributes of all members of organization can be difficult.

Leadership plays a key role in company restructurization especially in plantation business. The majority of state-owned plantation company requires corporate restructuring for profitization and/or privatization. According to theories and prior experiences, in a declining organization per-

Table 1. Total Employees, Total Production dan Employee Productivity of PTPN V Riau in 2005-2009

\begin{tabular}{ccccc}
\hline Year & $\begin{array}{c}\text { Total employees } \\
\text { (person) }\end{array}$ & $\begin{array}{c}\text { Total Production } \\
\text { (Tons) }\end{array}$ & $\begin{array}{c}\text { Productivity } \\
\text { per Person } \\
\text { Employed }\end{array}$ & $\begin{array}{c}\text { Increase/Decrease } \\
\text { in Productivity (\%) }\end{array}$ \\
\hline 2005 & 16,204 & $2,092,097$ & 129.11 & \\
\hline 2006 & 16,073 & $1,726,920$ & 107.44 & -16.78 \\
\hline 2007 & 16,130 & $1,865,936$ & 115.68 & 7.67 \\
\hline 2008 & 16,614 & $1,896,745$ & 114.17 & 1.31 \\
\hline 2009 & 15,581 & $1,567,266$ & 100.59 & -11.30 \\
\hline Reference: PTPN V Riau (2010) & & &
\end{tabular}

formance, restructurization process is more likely to succeed when originated from the leader. This is also relevant to the state-owned plantation company. Considering theneed of restructurization, it is necessary for the state-owned plantation companies to have leaders with advanced leadership quality (Nugroho, 2005). Without leader's sincerity to execute policies for the common good, it will be difficult to revitalize the state-owned plantation performance (BUMN Track, 2008).

In the effort to achieve its best performance, the Board of Directors of PTPN V Riau has made a great effort to achieve a significant breakthrough, as an example, through building corporate vision to be a "World Class Company"(BUMN Track, 2008).

The implementation of this corporate vision supported with strong leadership enabling changes in every aspect of the organization, which is known as transformational leadership. Transformational leadership articulates a vision of the future of the organization realistically, stimulates subordinates intellectually, and gives personal attention to diversity in the subordinate level.

According to Bass danAvolio (2003), transformational leadership is a change-orinted-leadership, where organization vision is not only formulated but also implemented through; first, idealized influence, where leader through his/her personal autonomy extraordinarily influences his/her subordinate. Second, inspirational motivation, the ability of leader to emotionally inspire, motivate, cheer, festive dan even praise his/her subordinates. Third, individualized consideration, the ability and responsibility of leaders to provide satisfaction and encourage subordinate's productivity. The leader tends to be friendly, informal, close to the subordinates, treat the suborndinates equally, provide advice, help and support for individual development. Fourth, intellectual stimulation reflectsthe ability of leaders to stimulate the subordinates intellectually through motivation.
Several influences of transformational leadership towards research variables are analyzed in this study. The first influence investigated is transformational leadership and job satisfaction. Transformational leadership is leadership that nurtures the need of personal development of followers, stimulates and inspires them to offer their best effort in reaching organizational goals

A relationship between employee satisfaction and work aspect is noted, Robbins (2006) demonstrates that job satisfaction is a pleasurable or positive emotional state resulting from the appraisal of one's job and perception of one's work quality with regard to its valuable contributions. Factors that contribute to employee satisfaction include: activities, compensation, independence reward, social status, and social services.

Job satisfaction is subjective in nature, where each individual experiences different level of job satisfaction. The more job aspects match individual's desire, the higher job satisfaction, and vice versa.

Accroding to Luthans (2005), there are three job satisfaction dimensions; first, job satisfaction is an emotional response towards job situation. Hence, job sastisfaction can be visualized and predicted. Second, job satisfaction is often determined by how well outcomes meet and exceed the expectations. Third, job satisfaction represents several related attitudes.

Dorman dan Zapf (2001), explains that there are two factors that influence job satisfaction, personnel and organizational factors. Personne factor involves personality aspects, status, seniority, job match dan life satisfaction. On the other hand organizational factor involves reward system, centralized authority, acceptance of supervisor, social and job reward as well as work environment. Job satisfaction is subjective in nature, where each individual experiences different level of job satisfaction. The more job aspects match one's 
desire, the higher job satisfaction, and vice versa. Tondok dan Andarika (2004) stated that transformational leadership gives a positive and significant influence towards job satisfaction. This is contrary to research finding by Sudarmasto (2005), which suggested that transformationa leadership does not significantly influence job satisfaction.

Secondly, in order to understand the influence of transformational leadership towards organizational commitment, one should note that transformational leader should possess the ability to articulate and align his/her vision to the subordinates, elevate those around them from a lower to a higher level of need. A vision should be transmitted through persuasion and inspiration, not by decision and directive statement. Effective leader use a combination of captivating rethoric, metaphors, slogan, symbols and rituals. Commitmen to the vision is strongly related to followers trust in their leader.

Oganizational commitment is defined as "The degree to which on employee identifies with a particular organization and its goals, and wishes to maintain membership in the organization", in which elements of organizational commitmen are: affective, normative and and rational (Robbins, 2006).

Affective commitment is originated from employee's emotional attachment to the organization. Employees with strong affective commitment will identify themselves through active participation and enjoying his/her involvement within the organization. Employees with high normative commitment will stay in the organization because they ought to do so. Rational commitment is related to commitment based on perception on the cost the employee associated with leaving the organization. In other words, employee with strong rational commitment will stay in the organization because they need to.
Commitment can be formed at the very beginning when individual initially joins as a member of organization, through well-developed socialization and orientation program. Employee understanding on company details, vision and mission through socialization and orientation program will hasten the unification of employee as an individual within the organization. Commitment directs individual to work according to the company expectation and individual expectation, which encourages better work performance (Luthans, 2005).

Tobing (2009) demonstrates that transformational leadership significantly influences organizational commitment. This research finding is further confirmed by Fortmann et al. (2003) who states that transformational leadership has a significant influence towards organizational commitment.

Basically, a leader should create organizational commitment to the follower by creating follower's trust. Trust not only depends on the leader's expertise, but also the leader's consistency in statements and attitudes.

Third, the next relationship analyzed is the influence of job satisfaction towards employee performance. One will tend to work passionately when job satisfaction is attained. This job satisfaction is the key for morality, discipline, employee performance in supporting company objectives. High employee satisfaction creates company/organization loyalty which later improves employee performance.

Employee performanceis defined as results obtained fromjob functions or activities performed as behaviour and results (Amstrongdan Baron, 2005). Evaluation towards employee performance can be assessed by several parties involved and by a representative evaluator. Robbins (2001) states that usually the best work evaluation is to be done by employee's direct supervisor. This is related to the fact that direct supervisor is the person responsible for his/her subordinate's performance for comprehensive evaluation.
Robbins (2001) also suggests that recently not all direct supervisor can directly observe subordinate's performance because of newly implemented performance system, such as independent team creation, distant work method which creates gap between the supervisor and the subordinates. Study conducted by Sudarmasto (2005) demonstrates that besides evaluator's factor, method used in performance evaluation should be well suited, to give respresentative results. There are five methods of individual performance evaluation.

Mathis dan Jackson (2002), states that, employee performance in the context of productivity de pends on three major factors; First, innate ability to accomplish task which consist of talent, interest, personality factor, and psychological factor. Second, employee effort level which includes motivation, work ethics, work attendance and work planning. Third, support provided to the work force such as training, tools, known expectation and productive work colleagues.

The above statements are in line with LussierdanAnchua (2001), which suggests that performance is a function of ability, job satisfaction, motivation and resources. Therefore, in order to increase performance, appropriate actions are required according to the causative factor.

Andrew (2004) finds that job satisfaction significantly influences tennis player's performance. This finding is supported with study done by Tobing (2009) which argues that job satisfaction significantly influences employee performance. In short, the higher the job satisfaction results in higher the employee performance.

Lastly, influence of organizational commitment on employee's performance is analyzed in this study. Commitment can initially be built at the initial point of contact of member within the organization, through well-developed socialization and orientation program. Employee understanding on company details, vision and mission, through socialization and orientation program accelerate the unification of employee as an individual within the organization. Commitment directs individual to work according to the company expectation and individual expectation, which provokes bette work performance (Luthans, 2005).

Prior research argues that organizational commitment is related to performance (Carmeli and Freund, 2004). Research done by Andrew (2004) involving the collection of samples from employees working in manufacturing and service companies, hypothesizes that organizational commitment is related to performance.

Based on above explanations in the context of the transformational leadership model, employee job satisfaction, organizational commitment and employee's performance, there are several reasons this research conducts which are; First, transformational leadership variable, employee job satisfaction, organizational commitment, employe performance are crucial elements for the succes of organizations and its employee, hence requiring in depth research. Second, results inconsistency in previous study with regard to relationship of transformational leadership and performance was noted. Hence, different research model need to be proposed for further investigation. Third, according to several theoreticalreviews and researches transformational approach in leadership model is highly relevant to organization facing global competition with major uncertainties and challenges.

The purposes of this research are; First, to prove and analyze the influence of transformational leadership towards employee job satisfaction; Second, to prove and analyze the influence of transformational leadership towards organizationa commitment; Third, to prove and analyze influence of transformational leadership towards employee performance; Fourth, to prove and analyze the influence of organization commitment towards employee performance. 


\section{Research Hypothese}

H1.Transformational leadership significantly influences PTPN V Riau employee job satisfaction

H2.Transformational leadership significantly influences PTPN V Riau organizational commitment

H3. Job satisfaction significantly influences PTPN V Riau employee performance.

H4. Organizational commitment significantly influences PTPN V Riau employee performance.

\section{Interpersonal Variables Research}

Initial hypothesis of this study is based on the importance of a leadership role in influencing job satisfaction of employees. In the job satisfaction of subordinates understand there is a correlation with aspects of the work, because basically it's own job satisfaction is an individual, where each individual will have the satisfaction level is different. More and more aspects of the work in accordance with the wishes of the individual, the higher the perceived level of satisfaction and vice versa.

In order to encourage the achievement of job satisfaction of subordinates, the leadership of the organization through transformational leadership should consider the relationship of these factors. If subordinates feel the needs and expectation are met will certainly try to devote myself entirely to sasran and organizational goals. The nex subordinate will work better when knowing tha the organization provides opportunities for growth (H1).

Transformational leadership must have the ability to match the vision of the future with his subordinates. A vision must be moved by persuasion and inspiration, not by a decision or force. Commitment to this vision is closely related to the belief that subordinates of leaders. It is impossible that a leader is not trusted can successfully achieve its commitment to a new vision for the organization. Trust depends on the perceived expertise of these leaders, but also depends on the consistency of the leaders in the statements and actions of leaders (H2).

Job satisfaction affects employee performance, meaning that an individual's performance will increase when the job satisfaction of individuals are at a high. A person tends to work with passion if satisfaction can be obtained from the work. Job satisfaction is a key driver of employee morale, discipline and work performance of employees in the company's goals in support tewujudnya. Job satisfaction is high, or both will make employees more loyal to companies or organizations. The higher the job satisfaction of employees will provide opportunities to achieve optimal performance (H3).

In principle, a commitment to grow the organization can be done in various ways. Commitment can be stimulated before someone becomes part of an organization such as carrying out a good selection to get the employees who actually have the perception, expectation, or the value corresponding to the organization. Or someone who will join the organization to understand where they work. Commitment can be formed when someone has just become part of the organization, through a program of socialization and a good orientation. Socialization and orientation program is essential to accelerate the organization's employees. Commitment can be formed even after someone for so long been part of the organization through a career path or provide enough job challenging. Commitment will be of great benefit to the development organization in the future, especially to improve employee performance (H4)

Relationship between research variables and research hypotheses can be seen in Figure 1 .

In Figure 1 are shown the positive influence of a variable to another variable, which is preceded by a variable that transformational leadership has a

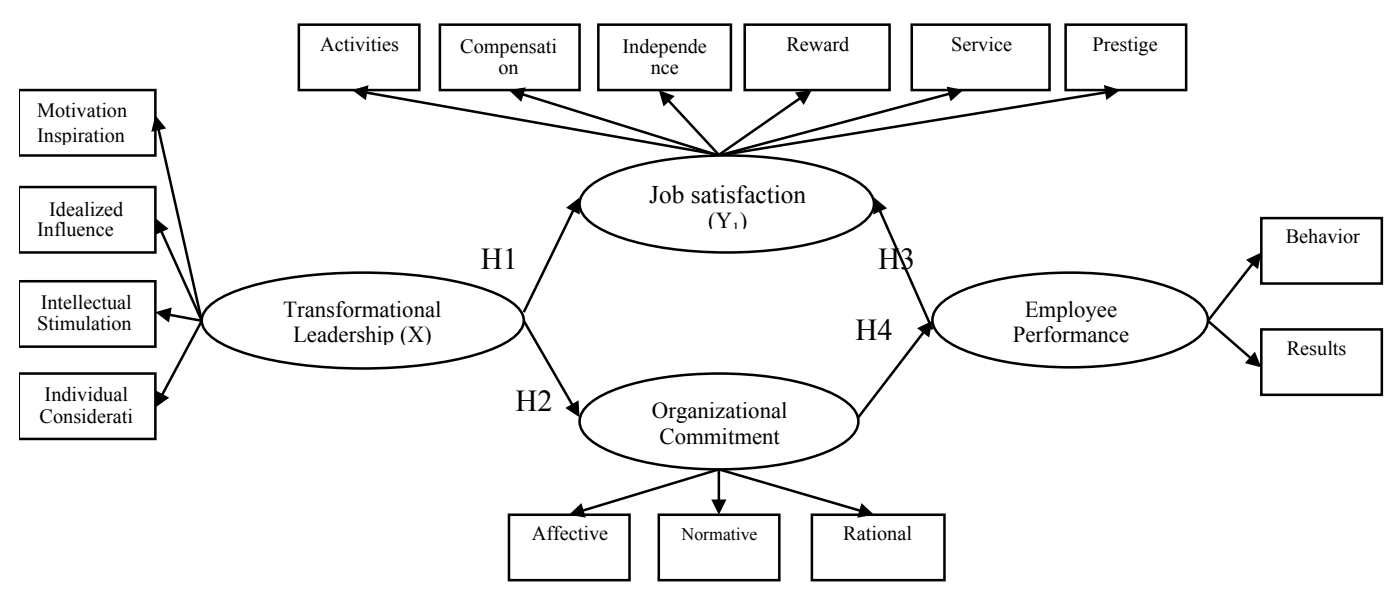

Figure 1. Relationship of research variables and research hypotheses.

positive effect on job satisfaction of employees. Further transformational leadership has a positive effect on organizational commitment of employees. Linking other variables that positively influence employee performance is the variable of job satisfaction. And finally a positive influence on organizational commitment to employee performance

\section{METHODS}

\section{Research Approach}

In order to answer research problems, this research employs quatitative and qualitative approaches. Quantitative approach was done to attain four research objectives which are: to analyze the influence of tranformational leadership on job satisfaction, organizational commitment and employee performance at PT. Perkebunan Nusantara (PTPN) V Riau. On the other hand, qualitative approach is used to obtain a big picture of the real transformational leadership, job satisfaction, organizational commitment and employee performance at PT. Perkebunan Nusantara $\mathrm{V}$, as one of the agribusiness enterprises in Riau Province.

\section{Place of Research}

This research was conducted at PT. Perkebunan
Nusantara V (PTPN V) Riau Provice, a plantation company which spreads across 5 Districts including Rokan Hilir District, Rokan Hulu District Kampar District, Siak District and Indragiri Hulu District.

\section{Research Populaton and Sample}

Population is a group individual or research objects which at least have one similar characteristics (Umar, 2003). Research population in this study is all permanent employees of PT.Perkebunan Nusantara V Riau in 2010. Employees included in this research are middle management employees consists of Head of Deparment, Plantation manager, Plant Manager, Head of Bureau/Division, Head Assistant, Head of Strategic Business Unit (SBU), Chief Engineer and Head of hospital, with the total of 146 respondents.

According to Ferdinand (2006), samples are the subset of population, consisting of several part of population. Sample size has important role in the estimation and interpretation of SEM results. Hai and Ferdinand (2006) suggests that appropriate sample size for SEM analysis is between 100-200. If the sample size is too large $>400$, the analysis becomes so sensitive that it is difficult to obtain a good measure of Goodness-of-fit. 
Sampling technique used in this study is Census Method, a techique of sample selection where all population are considered as samples(Umar 2003) which is 146 . In other words, the total research samples has fulfilled the data analysi criteria using Structural Equation Modeling (SEM). The distribution of research respondents can be clearly seen in Table 2 .

\section{Research Variables and Measurement}

\section{of Variable Indicators}

Research variables can be classified into: First, exogenous variable, variable that are not predicted by other variables in the model (Ferdinand, 2006). It is also known as source variable atau independen varible. In this research, exogenous variable is transformational leaderhip (X1). Second endogenous variable, a variable that is predicted by one or more variables in the model (Ferdinand 2006). There are two endogenous variables in this research; First, variable affected when the exogenous variable influences the endogenous variable (Sekaran,2003). In this research the intervening variable is job satisfaction (Y1) and organizational commitment (Y2). Secondly, dependent endogenous variable or dependent variable. The endogenous variable is employee performance (Y3)
The indicators of transformational leadership, job satisfaction, organizational commitment and employee performance variables were red through PTPN V Riau middle manager's perception, using questionnaires. The questionnaire consists of several questions based on relevant theory related to each analyzed variable. The 5 point Likert scale was used to measure attitude, opinion and perception of an individual or a group of people about social phenomena (Sugiyono, 2006). The transformational leadership indicators, which include idealized influence, inspirational motivation, individualized consideration and intellectual stimulation (Bass dan Avolio,2003) were measured through middle manager's perception on the scale of: strongly disagree $=1$, disagree $=2$, quite agree $=3$, agree $=4$, strongly agree $=5$. Employee work satisfaction variable was measured with following indicators: activity, compensation, independence, reward, social status, and social services (Robbins, 2006), having the attribute of very dissatisfied $=1$, dissatisfied $=2$, quite satisfied $=3$, satisfied $=4$ and very satisfied $=5$. Furthermore, organizational commitment's indicators are affective, normative and rational (Robbins, 2006) measured in the scale of: strongly disagree $=1$, disagree $=2$, quite agree $=3$, agree $=4$, strongly agree $=5$. Lastly, the employee performance
Table 2. Distribution of Total Middle Management Employees at PTPN V Riau in 2010

\begin{tabular}{lc}
\hline \multicolumn{1}{c}{ Field/ Division (Position) } & Total (person) \\
\hline Head of Department & 14 \\
\hline Plantation Manager & 27 \\
\hline Plant Manager & 10 \\
\hline Head of Bureau/Division & 40 \\
\hline Head Assistant & 34 \\
\hline Head of SBU & 15 \\
\hline Head of Engineer & 3 \\
\hline Head of Hospital & 3 \\
\hline \multicolumn{1}{c}{ Total } & 146 \\
\hline
\end{tabular}

Reference: PTPN V Ria

Table 3. Goodness of Fit Indexes for Model Evaluation

\begin{tabular}{ccl}
\hline Index Testing & Criterion & Remarks \\
\hline$X^{2}$ (Chi - Square Statistics) & $\begin{array}{l}\text { Small value } \\
\text { expected }\end{array}$ & $\begin{array}{l}\text { Testing whether population covariace } \\
\text { estimated to be the same as sample } \\
\text { covariance (research model proposed } \\
\text { according to field data) }\end{array}$ \\
\hline Probability & $\geq 0.05$ & $\begin{array}{l}\text { Significance test towards covariance } \\
\text { matrixand estimate of covariance matrix }\end{array}$ \\
\hline RMSEA & $\leq 0.08$ & $\begin{array}{l}\text { Compensate the weakness of Chi - Square } \\
\text { in large sample size }\end{array}$ \\
\hline GFI & $\begin{array}{l}\text { Calculateaweighted proportionofvariance } \\
\text { in sample matrix accounted for by the } \\
\text { estimated population covariance matrix } \\
\text { (analog R in double linear regression) }\end{array}$ \\
\hline AGFI & $\geq 0.90$ & \begin{tabular}{l} 
GFI adjusted to DF \\
\hline CMIN/DF
\end{tabular} \\
\hline TLI & $\leq 2.00$ & $\begin{array}{l}\text { Coherence between research data and } \\
\text { model }\end{array}$ \\
\hline GFI & $\begin{array}{l}\text { Comparison between investigated model } \\
\text { and baseline model. } \\
\text { Model applicability testing insensitive to } \\
\text { sample size and complexity of model. }\end{array}$ \\
\hline Reference: Ferdinand (2006) danSolimun (2004) &
\end{tabular}

variable indicators includes: behavior and results (Amstrongdan Baron, 2005) with the attribute of: strongly disagree $=1$, disagree $=2$, quite agree $=$ 3 , agree $=4$, strongly agree $=5$.

\section{Type and Source of Data}

There are two kinds of data collected in this research, primary and secondary data. Primary data were collected through direct interview with respondents with the use of questionnaire. On the other hand, secondary data were collected from several sources mainly from PT. Perkebunan Nusantara V Riau.

\section{Data Collection Technique}

The data collection technique employed questionnaire distribution, where the data are collected based on the list of questions designed to meet the intended objectives. The questionnaire was distributed to each respondent and each questionnaire item was organized according to the research variables. The questionnaire was directly distributed to respondents with the help of related department handling the human resource matters. Respondents were explained on the instruction of use, focusing on the objective and the aim of study for easier understanding and questionnaire completion. Secondly, in additio to questionnaire, interview technique was also used. The interview was conducted directly to respondents/employees during their work to obtain technical information and data to furthe add, support, complete any data that have no been covered in the questionnaire.

\section{Data Analysis}

\section{Validity and Reliability Testing}

Data hold important role in a research because they reflects the variable in question and functioned as a tool for hypothesis test.Data validity represents the data quality. This relies on the instrument used which fulfills the validity and realibility principles.

The Confirmatory Factor Analysis (CFA) was applied to test instrument's validity and realibility. The detailed results were presented in Appendix 1. The instrument is considered validunidimensionalfor GFI score $>0.90$ and considered reliable forConstruct reliability score $>0.70$ (Ferdinan, 2006). 


\section{Descriptive Analysis}

Descriptive analysis data is used to figure out variable's characteristics that are measured by several indicators. Descriptive statisticsprovides frequency, mean, the maximum and the minimum value of each indicator

\section{HypothesisTesting}

The influential pattern observed in investigated variable is a causal relationship between one or more independent variables and one or more dependent variables. The causal relationship presented, utilizes an unsimplified research model: the presence of variable with dual role, as an independent variable in one case and as a dependent variable on the other case. This relationship requires analytical tool that is able to simultaneously explain the relationships. Structural Equation Modeling (SEM) was used to test and analyze relationship between research variables using AMOS software (.Ferdinand, 2006), suggested the Goodness of Fit Indexto evaluate research model. It is shown in Table 3.

\section{RESULTS AND DISCUSSION}

\section{Test of Instrument Validity and Reliability}

Results oftest instrument validity andreliability of

each variable are shown in Table 4 .

The result of instrument validity and reliability test presented in Table 4 indicates that all researchvariabls are valid and reliable (GFI score $>0.9$ and construct reliability $>0.7$ ).

\section{Decriptive Variable}

The result of decriptive analysis includes frequency, which is attained from tabulation of 146 responses scores, shown below:

- Responses on Transformational Leadership Indicators

Respondent's perceptions towards transformational leadership are: idealized influence (4.29), insipiring motivation (4.19), intellectual stimulation (4.25) and individual consideration (4.13). This result indicates that the influence/response for each leadership dimension is relatively uniform with Standard deviation of less than 1.

Responses on Job Satisfaction Indicators

Respondent's perceptions towards job satisfaction are: activities (4.14), compensation (4.22), independence (4.11), reward (4.22), service (4.24) and prestige (4.40). The response to each job satisfaction dimension is quite uniform with the S.D of less than 1.

Responses on Organizational Commitment Indicators

Respondent's perceptions on organizational commitment are: affective (4.23), normative (4.12),and rational (4.34). Similarly, uniformity of reponses is observed with a lower than 1 standard deviation.

Responses on Organizational Employee Performance

Employee performance ispercepted as: behavior (4.24) and results(4.35). The response of each work motivation dimention shows uniformity, with a standard deviation of less than 1.

Table 4. Results of Validity and Reliabililty Instrument Testing

\begin{tabular}{ccc}
\hline Variable & GFI & Construct Reliability \\
\hline Transformational Leadership $\left(\mathrm{X}_{1}\right)$ & 0.953 & 0.919 \\
\hline Job Satisfaction $\left(\mathrm{Y}_{1}\right)$ & 0.958 & 0.853 \\
\hline Organizational Commitment $\left(\mathrm{Y}_{2}\right)$ & 1.000 & 0.967 \\
\hline Employee Performance $\left(\mathrm{Y}_{3}\right)$ & 0.986 & 0.809 \\
\hline
\end{tabular}

Reference : Data analysis (2010)
Results of the Analysis of SEM and Hypothesis Test Model Testing

Results of Goodness of fit overall modeltest, done to understand whether hypothesized model supported with empirical data, are presented in Table 5.

According to the result of the Goodness of fit overall model test presented in Table 5, it can be concluded that the seven criteria used model feasibility testing have fulfilled the requirement, without requiring any further adjustment. This indicates good fit of the measurement model and hence proposed model considering data and research model coherence.

\section{Hypothesis Test}

Results of hypothesis test between research

Table 5. Results of Goodness of Fit Overall Model Test

\begin{tabular}{cccc}
\hline Criteria & Cut-of value & Results & Remarks \\
\cline { 1 - 3 } Chi- Square & Small & 157.410 & Good Model \\
\hline p-value & $\geq 0.05$ & 0.634 & \\
\hline CMIN/DF & $\leq 2.00$ & 1.227 & Good Model \\
\hline GFI & $\geq 0.90$ & 0.986 & Good Model \\
\hline AGFI & $\geq 0.90$ & 0.952 & Good Model \\
\hline TLI & $\geq 0.95$ & 0.973 & Good Model \\
\hline CFI & $\geq 0.95$ & 0.977 & Good Model \\
\hline RMSEA & $\leq 0.08$ & 0.045 & Good Model \\
\hline
\end{tabular}

Reference : Data analysis (2010)

Table 6. Results of Hypothesis Test of Variables Influence

\begin{tabular}{clcccc}
\hline No & Independent Variable & Dependent Variable & Path Coefficient & $\mathrm{p}$-value & Remarks \\
\hline 1 & $\begin{array}{l}\text { Transformational } \\
\text { leadership }(\mathrm{X})\end{array}$ & Job satisfaction $\left(\mathrm{Y}_{1}\right)$ & 0.984 & 0.035 & Significant \\
\hline 2 & $\begin{array}{l}\text { Transformational } \\
\text { leadership }(\mathrm{X})\end{array}$ & $\begin{array}{c}\text { Organizational } \\
\text { Commitment }\left(\mathrm{Y}_{2}\right)\end{array}$ & 0.635 & 0.004 & Significant \\
\hline 3 & Job satisfaction $\left(\mathrm{Y}_{1}\right)$ & $\begin{array}{c}\text { Employee Performance } \\
\left(\mathrm{Y}_{3}\right)\end{array}$ & 0.642 & 0.003 & Significant \\
\hline 4 & $\begin{array}{c}\text { Organizational } \\
\text { Commitment }\left(\mathrm{Y}_{2}\right)\end{array}$ & $\begin{array}{c}\text { Employee Performance } \\
\left(\mathrm{Y}_{3}\right)\end{array}$ & 0,968 & 0.034 & Significant \\
\hline $\begin{array}{l}\text { Notet: } * * * * \\
\text { Reference }: \text { : Data analysis }(2010)\end{array}$ & & & & \\
\hline
\end{tabular}

variables in each pathaccording to SEManalysis,are concisely presented in Table 6 .

According to Table 6,the hypothesis test suggested cantly influences job satisfaction. This is shown by the path coefficient of 0.984 , with significance probability of 0.035 . Therefore, transformationa leadership significantly influences job satisfac tion by 0.984 , which means that each incremen of transformational leadership, will result in the increase of job satisfaction by 0.984 . The findin supports the hypothesis stating thattransformational leadership significantly influences PTPN Riau employee job satisfaction. Secondly, transformational leadership significantly influences coefficient result of 0.635 and significance probathat; First, transformational leadership signiforganizational commitment. Based on the path 
bility of 0.004 transformational leadership is significantly shown to influence employee organizational commitment. Transformational leadership significantly influences employee organizational commitment by 0.635 , which means that every increase in transformational leadershippromote the employee's organizational commitment by 0.635. This research finding further confirms the hypothesis which states that transformational leadership significantly influences PTPN V Riau employee organizational commitment. Third, job satisfaction significantly influences employee performance. This is evident from path coefficien of 0.642 , with significance probability of 0.003 . Therefore, employee job satisfaction significantly influences employee performance by 0.642 , implying that the increase in job satisfaction by one scale, rises employee performanceby 0.642 . The positive correlation supports the initial hypothesis stating that job satisfaction significantly influences PTPN V employee performance. Fourth, organizational commitment shows a statistically significant influence on employee performance.This is shown by path coefficient that scored 0.968 and significance probability of 0.034 . In other words, organizational commitment influences employee's performance by 0.968 , indicating tha every improvement in organizational commitmen will increase employee's performance by 0.968 . Similarly, the research finding further confirms the hypothesis which mentioned that organizational commitment significantly affects PTPN V Riau employee performance.

\section{Transformational Leadership Significantly} Influences PTPN V Riau Employee

\section{Job Satisfaction}

Research finding shows that transformational leadership significantly influences employee job satisfaction. This indicates the higher transformational leadership quality of middle management, the higher employee job satisfaction. In short, there is enough empirical evidence to accept hypothesis $\left(\mathrm{H}_{1}\right)$ which states transformational leadership significantly influences employee job satisfaction
This findings are aligned with results of other study by TondokdanAndarika (2004), which mentioned that transformational leadership have a positive and significant impact on job satisfaction. However, this finding is contrary to the research by Sudarmasto (2005), which suggested that transformational leadership did not significantly influence job satisfaction.

Furthermore, research resultsare in line with Robbin'sfinding (2001). There are several influential process found as a result of transformational leadership. The firstis the influence of transformational leadership towards job satisfaction. Transformational leadership is a leadership that considers the need of individual self-development as well as stimulating and inspiring the followers to accomplish more in reaching theirwork goals.

Robbins (2001) concept was supported withSudarmasto(2005), which suggested that transformational leadership is change-oriented leadership, in which organization vision is not only formulated but also implemented.

According to Bass andAvolio (2003), transformational leadership is change-oriented leadership, in which organization vision is not only formulated but also implemented through; First,idealized influence. Leader, through personal authority can extraordinarily influence his/her subordinates. In the context of PTPN V, the idealized influence arises in a consistent leader. The subordinates not only admire and respect but also trust the leader. As an example, before enforcing discipline to the subordinates, leaderfirst nurturesa self-disciplined attitude.The second is inspirational motivation.

This refers to leader's ability to emotionally inspire, motivate, cheer, festive dan even praise his/her subordinates. In this research, the manager provides support and encouragement to the subordinates to achieve organization goals, employee promotion is provided as a reward. Third, individualized consideration, the ability and responsibility of a leader in providing satisfaction and encourage subordinate's productivity. The leader tend to be friendly, informal, close to his/her subordinate and treat them equally, providing advice, help and support for personal development.For instance, the plant manager of PTPN V Riau encourages the subordinates to continuously enhance their career prospects through improvement in productivity. In this way, an employee can be recommeneded for advancement in rank or position in the company. The lastly is intellectual stimulation. It is the ability of a leader to intellectually stimulate his/her subordinates through motivation. For an example, leaders at the plant managerlevel at PTPN V Riau, allows the subordinates to communicate any problems and issues as well as the potential proposed solutions.

To further understand job satisfaction, it should be noted that job satisfaction is subjective in nature, where each individual experiences different level of job satisfaction. The more job aspects match individual's desire, the higher job satisfaction, and vice versa.

\section{Transformational Leadership Significantly In-} fluences the PTPN V Riau Employee Organizatio-

\section{nal Commitment}

This study found that transformational leadership insignificantly influences employee organization commitment. Hence, the transformational leadership at PTPN V Riau has significant influence on employee organization commitment. In conclusion, there is not enough empirical evidence to accept the hypothesis $\left(\mathrm{H}_{2}\right)$ which states that transformational leadership significantly influences employee organizational commitment.

Research by Tobing (2009) finds that transformational leadership has significant influence on organizational commitment. This finding is further supported with study done by Fortmann et al. (2003) which proposes significant influence of transfomational leadership towards organizational commitment.
Transformational leadership improves organizational commitment, for instance, through the ability of middle management to assist their subordinate's career advancement or involve them in training programs. This creates reluctancy for employees to leave the company because of the potential of career advancement.

Direct transformational leadership canincrease organizational commitment. A leader should emphasize the subordinates to do their utmost work as they are part of the organization.

Furthermore, transformational leadership also enhances organizational commitment of the subordinatesthrough vision transmission. Commitment to company vision is strongly related to follower's trust in the leader. The transformational leadership applied in PTPN V Riau is shown to strengthen organizational commitment by emphasizing subordinates to do their utmost work, considering that they are part of the organization.

\section{Job Satisfaction Significantly Influences the PTPN} V Riau's Employee Performance

The study results demonstrate that job satisfaction significantly affects employee's performance. As previously mentioned, the higher PTPN V Riau's employee job satisfaction the higher their performance are. In short, there is enough empirical evidence to accept Hypothesis 3 (H3) which states employee job satisfaction significantly influences employee's performance.

This is in line with study done by Andrew (2004) which argues that job satisfaction significantly influences tennis player's performance. Simila finding is suggested byTobing (2009) which demonstrates that job satisfaction significantly influences employee performance. Shortly, the higher the job satisfaction results in higher the employee performance.

Employee satisfaction impacts on improvement in PTPN V Riau's employee performance. In order to 
achieve optimal performance, a plantation manager must be responsible to any issues related to region/sector allocated as his/herareaofresponsibility. For instance, plantation unit A requires a plantation assistant. If positive work performance was observed, the person would be promoted to handle wider section, as an example, plantation sector type B. This reward system stimulates job satisfaction to the employee because the workload/responsibility is delegated according to one's ability. The job satisfaction therefore, increases work performance.

\section{Organizational Commitment Significantly}

Influences PTPN V Riau Employee Performance

Results of this study show organizational commitment has positive and significant influence towards employee performance. As mentioned previously, the higher employee organization commitment, the higher the performance. In conclusion, there is enough empirical evidence to accept Hypothesis 4 (H4) which states organizational commitmen significantly influences employee performance.

This empirical finding is in line with previous research which illustrates the relationship of organizational commitment to performance (Carmeli and Freund, 2004). Similar findings were noted in research done by Andrew (2004) involving the collection of samples from employees working in manufacturing and service companies. The study demonstrates that organizational commitment is also related to performance.

The employees of PTPN VRiau are committed to improve their performance which further impact on company profit and bonus/reward distribution. The pride and gratefulness of working in a stateowned company motivates employees to be responsible and better in performance.Highly commited employees tend to believe that the job is the main source of income for the family. In PTPN V Riau, employee achievement is always appreciated both financially and non-financially. Employees are valued as company's asset.

\section{MANAGERIAL IMPLICATIONS}

From the analysis and findings of research conducted, resulting implications in the field of human resource management, especially those associated with transformational leadership, job satisfaction, organizational commitment and employee performance. Of the relationship between variables indicate if the study confirm previous research work, therefore the results of this study can be an empirical reference for the practitioner to implement important policies related to these variables along with examining the indicators used in this study.

Obtained in addition to the positive implications, this study also has limitations of the study. Although already qualified the use of SEM, but research is still using relatively few respondents compared to the possibility of many employees who engage in transformational leadership. Another limitation is the subject of this study involved only middle manager, the PT. Nusantara V,. Developed a possible future studies that use subjects who engaged in similar businesses and industries, such as PT. Plantation and PT Nusantara II. Nusantara III plantation in North Sumatra and PT. VII Nusantara Plantation in Lampung province.

Further assume that this research model to build on this research is only determined by a series of transformational leadership variables, job satisfaction, organizational commitment and employee performance. Yet the reality may not be as simple as that. Fore expected to add other important variables such as, competencies, education and training, organizational culture, innovation, compensation and work environment.

\section{CONCLUSION}

1. Tranformational leadership significantly influences employee job sastifaction at PTPN V Riau. In other words, tranformational leadership should be able to understand the diverse need of individuals. The more work aspects match with the individual desires,the higher employee job satisfaction at PTPN V Riau.

2. Tranformational leadership significantly influences employee organization commitment at PTPN V Riau. This implies that transformational leadership should encourage employee's trust. Trust building relies on leader's expertise and leader's consistency in articulating statements and attitudes. As a result, transformational leadership improves employee's organizational commitment at PTPN V Riau.

3. Job satisfaction significantly influences PTPN $\mathrm{V}$ Riau employee performance, suggesting that job satisifaction improves PTPN V Riau employee performance. Satisfied employee has better performance than those unsatisfied. The satisfaction results in happiness which means that the company meets employee's work expectation.

4. Organizational commitment has significant influence on PTPN V Riau's employee performance. The finding implies that job satisfaction enhances PTPN V Riau's employee performance. A high level of organizational commitment promotes loyalty to the company.

\section{Recommendations}

1. The theoriesthat have been developed in this research can be further developed and continued in the future research conduct, to create more comprehensive problem solving model for transformational leadership, job satisfaction, organizational commitment and employee performance.

2. PTPN V Riau leaders should predominantly implement transformational leadership in every leadership layer, especially in the middle management level.

3. The leader and the management of PTPN Riaushould increase the employee's work satisfaction level. Furthermore, the middle management should optimize their capabilities in reaching the set target to improve employee performance. Efforts in developing job satisfaction should focus on the main contributing factors such as: activities, compensation, independence, reward, social status and social services.

4. The leader and the management of PTPN Riaushould enhance organizational commitment. This can be done through embedment of company vision through the three aspects of commitment, namely affective, normative and rational commitment.

\section{REFERENCES}

Amstrongdan Baron. (2005) Managing Performance; Performance Management in Action, Chartered Institut of personal and development, House, London.

drew J. Dubrin, (2001) Rochester Institute of Technology. Leadership, Research Findings, Practice, and Skills. Third Edition Houghton Miffin Company,Boston New York.

Andreas Lako, (2004). Kepemimpinan dan Kineja Organisasi. Penerbit; Amara Books. Yogyakarta.

Avolio, B. J., \& Bass B. M. (2002). Manual for the Multifaktor Leadership Questionare (from 5X), Redwood City, CA: Mindgarden. BambangTriadji (2002). Pengaruh Birokrasi dan gava kepemimpinan terhadap kepuasan kerja karyawan dan kineria Badan Pemeriksaan Keuangan Republik Indonesia, Universitas Pajajaran, Bandung.

Bass, B. M, Avolio. B. J., Jung, D. Berson. Yair. (2003). Predicting Unit Perfomance by Assesing Transformational and Transactional Leadership, Journal of Applied Psychologi 2003, Vol 88, № 2, p.207-218.

Bacal,Robert,2002, Peformance Management Memberdayakan Karyawan, Meningkatkan Kinerja Melalui Umpan Balik, Mengukur Kinerja, Mc Graw Hill/Gramedia, New York.

BUMN Track, 2008, Menakar Kinerja BUMN Tahun 2007, EdisiJuni, Hal. 54-55. , 2008, Kita Perlu Green Revolution Baru, Edisi Juli, Hal 76-79.

Carmeli, Abraham and Anat Freund, 2004, Work Commitment, Job Satisfaction and Job Performance: An Empirica Investigation, International Journal of Organizational Theory and Behaviour, Vol.7, N0.3, Academic Research Library,
p. 289-309 
Conger A. J. \& R. N. Kanungo\&Menon T.S 2000, Charismatic Leadership in and follower effect. Journal of Organizational Behaviour. Vol. 21. No.7.p.747-767.

Damon Patrick Sermans Andrew (2004): The Effect of Congruence of Leadership Behaviours on Motivation, Comitment, and Satisfaction of Tennis Player. College Education The Florida State University.

Diana Sulianti K.L, Tobing (2009), Pengaruh Kepemimpinan Transformasional Terhadap Kepuasan Kerja, Komitmen Organisasional Dan Motivasi Serta Kinerja Karyawan PTPN II. III. IV di Sumatera Utara, Program Pasca Sarjana Universitas Airlangga.

Dong I, Jung and Bruce J. Avolio 2000, Opening The Black Box: an Experimental Investigation of the mediating Effects of trust and value cocruence on Transformational and Transaktional Ieadership. Journal of Organizational Behavior, Vol. 21, No.8,p. 949-964.

Dormann.Christian and DieteZaft, 2001. Job Satisfaction: A Meta-Analysis of Stabilities. Journal of Organizational Behavior, Vol. 22, No.5, p.483-505.

Ferdinand, Augusty 2006. Structural Equation Modelling dalam Penelitian Manajemen. Edisi 4. Semarang: Badan Penerbit Universitas Diponegoro

Gibson, Ivancevich, Donnelly 2000. Organizational Behavior, Structure, Processes. Tenth Edition, Irwin McGraw-Hill.

Husen Umar, 2003, Metode Riset Perilaku Organisasi, PT. R. Grafindo Persada, Jakarta

Kristen Foortmann, Benyamin A. Feinzimer, Chris Thomson, Brooke Glover, Alethea Moraes and Mark, Fram, 2003, The Effects of Tranformational and Transactional Leadership on Affective Organizational Commitment, Poster Session presented at $24^{\text {th }}$ Annual IOOB conference, Akron, OH,Vol. 15, No.1. p. 1-7

Luthans,Fred.2005. Organization Behaviour. Tenth Edition, McGraw- Hill Companie

Lussier, Robert n and Achua, Christopher, 2001, Leadership; Theory Application, Skill Development. Cincinati' South Western College Publishing.

Mark Mac Donald, 2003, Transformational Leadership and High Performance Work System Practis and Fasilitator of Knowledge Work Behaviour, Queens School of Business.

Mathis,Robert I, Jacson, Jhon, 2002, Manajemen Sumberdaya Manusia, EdisiPertama, Salemba Empat, Jakarta

Mas'ud Fuad, 2004, Survei Organisasional Konsep dan Aplikasi, Universitas Diponegoro, Semarang.

Nugroho, Riant D, 2005, BUMN Indonesia Isu dan Kebijakan dan Strategi, PT. Elek media Komputindo, Jakarta.

PTPN V Riau, 2010, Laporan Tahunan Manajemen Perusahaan, Pekanbaru, Riau.

Robbins S P (2006), Organizational Behavior, Up Saddle River, New Yesrey, Prentic-Hall. (2001) Organizational Behavior, Prentice Hall, Inc, Upper Saddle Riverv, New Jersey.

Sakaran, Umar, 2003, Research Methods for Busness, Jhon Willey and Son, Inc, New York.

Solimun, M, S, 2004 Pemodelan Statistika, Structural Equation Modelling (SEM) aplikasi Amos, Diklat pada Universitas Riau, Pekanbaru.

Sudarmasto,2005, Analisis Pengaruh Struktur Organisasi, Kepemimpinan Transformasional, Kepemimpinan transaksional, Nilai-Nilai Budaya dan Motivasi terhadap Kinerja individual peneliti pada unit pelayanan teknis Riset di Departemen Perindustrian, Disertasi Fakultas Ilmu Sosial dan Ilmu Politik, Universitas Indonesia.

Sugiyono, 2006, Metode Penelitian Bisnis, Alfabeta, Bandung.

Tondok, Marselius Sampe dan Rita Andarika (2004), Hubungan Antara Persepsi Gaya Kepemimpinan Transformasional dan Transaksional dengan Kepuasan Kerja Karyawan, Jurnal Psycho, Fakultas Psikologi Universitas Bina Darma, Palembang Vol.1, No. 1, hal 1-15. 